\title{
Do dietary amino acid profiles affect performance of larval gilthead seabream?
}

\author{
Cláudia Aragão ${ }^{1 a}$, Luís E.C. Conceição, Marc Lacuisse, Manuel Yúfera and Maria Teresa Dinis \\ ${ }^{1}$ CCMAR, Universidade do Algarve, Campus de Gambelas, 8005-139 Faro, Portugal \\ 2 Instituto de Ciencias Marinas de Andalucia (CSIC), Apartado Oficial, 11510 Puerto Real, Cádiz, Spain
}

Received 8 January 2007; Accepted 6 June 2007

\begin{abstract}
Live preys commonly used in fish larval rearing seem to be imbalanced in terms of amino acids. Manipulation of their amino acid composition is difficult, but the use of microencapsulated diets allows this manipulation. This study analysed the effect of amino acid supplementation, in order to compensate for dietary amino acid imbalances, on growth and survival of gilthead seabream (Sparus aurata) larvae. Larvae were reared until 32 days after hatching, in a closed recirculating water system $\left(19^{\circ} \mathrm{C}\right)$, using only live food (rotifers and Artemia). Thereafter, larvae were fed Artemia or one of the experimental microencapsulated diets: supplemented with indispensable amino acids (IAAsup diet), or supplemented with dispensable amino acids (DAAsup diet). Experiment lasted for 10 days. Dietary supplementation with indispensable amino acids resulted in $\mathrm{A} / \mathrm{E}$ ratios [(each indispensable amino acid) $\times$ (total indispensable amino acids $\left.)^{-1} \times 1000\right]$ more similar to the ones of larval seabream and in higher IAA:DAA ratios than in the DAAsup diet. Survival was similar in larvae fed the IAAsup diet (75\%) or Artemia (87\%), but was significantly lower in larvae fed the DAAsup diet (52\%). Larvae from all treatments more than doubled their average dry weight during the experimental period. Final dry weight was similar in larvae fed both microcapsules, but these were lighter than larvae fed with Artemia. Relative growth rate (RGR) and total biomass production tended to be higher in larvae fed the IAAsup $\left(\mathrm{RGR}=9 \% \mathrm{day}^{-1}\right)$ than the DAAsup diet $\left(\mathrm{RGR}=7.5 \%\right.$ day $\left.^{-1}\right)$ and only in this last treatment these parameters were significantly lower than in larvae fed with Artemia. Therefore, dietary supplementation with indispensable amino acids resulted in a more balanced dietary amino acid profile, which significantly increased survival. Further studies introducing microdiets earlier in the development seem necessary in order to optimise growth.
\end{abstract}

Key words: Amino acids / Growth, Fish Larvae / Microencapsulated diets / Sparus aurata / Survival

Résumé - La composition en acides aminés, dans le régime alimentaire des larves de daurade royale, affecte-t-elle leur performance? Les proies vivantes utilisées dans les élevages larvaires semblent déséquilibrées en terme d'acides aminés. Manipuler la composition en acides aminés est difficile mais l'usage d'aliments encapsulés le permet. Cette étude analyse l'effet d'une supplémentation en acides aminés sur la croissance et la survie des larves de daurade royale (Sparus aurata) afin de compenser un déséquilibre. Les larves sont élevées jusqu'à 32 jours après éclosion en circuit fermé (eau à $19^{\circ} \mathrm{C}$ ), en utilisant des aliments vivants uniquement (rotifères et Artemia). Les larves sont ensuite nourries avec des Artemia ou bien avec des aliments microencapsulés expérimentaux, supplémentés en acides aminés soit indispensables (régime IAAsup) soit non-indispensables (régime DAAsup). La durée de l'expérience est de 10 jours. La supplémentation en acides aminés indispensables conduit à des ratios $\mathrm{A} / \mathrm{E}$ [(chaque AA indispensable) $\times$ (total en AA indispensables) ${ }^{-1} \times 1000$ ] plus proches de ceux de la larve de dorade et des ratios IAA/DHA plus élevés que ne le fait la supplémentation en acides aminés non-indispensables. Le taux de survie est similaire chez les larves nourries avec le régime IAAsup (75\%) ou Artemia (87\%) mais inférieur significativement chez les larves soumises au régime DAAsup $(52 \%)$. Le poids sec moyen de ces larves, quel que soit leur régime alimentaire, a doublé durant la période expérimentale. Le poids sec est similaire chez les larves nourries de microcapsules mais moins élévé chez celles nourries d'Artemia. Le taux de croissance relative (RGR) et la production de biomasse totale tendent à être plus élevés chez les larves nourries en IAAsup (RGR $=9 \%$ jour $^{-1}$ ) que celles nourries en DAAsup $\left(\mathrm{RGR}=7,5 \%\right.$ jour $\left.^{-1}\right)$. C'est seulement dans ce dernier traitement que les paramètres sont plus faibles significativement que chez les larves nourries d'Artemia. Ainsi, les supplémentations alimentaires en acides aminés indispensables peuvent augmenter la survie. D'autres études, introduisant des micro-aliments de façon plus précoce dans le développement, semblent nécessaires afin d'optimiser la croissance.

a Corresponding author: caragao@ualg.pt 


\section{Introduction}

Fish larvae have higher growth rates and energy requirements than juvenile and adult fish. Growth is essentially protein deposition (Carter and Houlihan 2001) and amino acids are the building blocks. Protein synthesis requires that all indispensable amino acids are present at an optimum ratio to each other (Carter and Houlihan 2001). If one indispensable amino acid is found to be deficient, then the other indispensable amino acid will be considered in excess and will be deaminated and used for other purposes than protein synthesis, such as energy production, lipogenesis, or gluconeogenesis (Ballantyne 2001). Since proteins are the only form of amino acid storage, dietary amino acid imbalances will result in unavoidable amino acid losses. Still, fish larvae have highenergy requirements and a large portion of amino acids is used as metabolic fuel (Rønnestad and Conceição 2005). Therefore, part of the dietary amino acids is always used as energy source and there is always an obligatory amino acid loss. Considering the high potential for growth and the high food intake of fish larvae, the amino acid losses due to dietary deficiencies may have a much larger negative impact on growth and food conversion efficiencies than in older fish (Conceição et al. 2003a). Therefore, dietary protein should be supplied in the right quantity and quality to sustain optimal larval growth and development.

The larval rearing of most marine fish species still relies on the use of live preys, at least during their early stages. Poor results in terms of growth and survival have been obtained in several studies when using a microdiet in the absence of live food during these early stages (Tandler and Kolkovski 1991; Fernández-Díaz and Yúfera 1997; Kolkovski et al. 1997a; Takeuchi et al. 2003). Rotifers and Artemia are the cultured zooplankters widely used in larviculture, but these preys are imbalanced in terms of amino acids as a diet for fish larvae (Conceição et al. 2003a; Aragão et al. 2004a). The manipulation of the amino acid profile of live prey is not easily achieved and the possible changes rely essentially on the modification of the free amino acid pool, which represents less than $10 \%$ of the total amino acid pool (Aragão et al. 2004b). In recent years, a protein-walled microencapsulated diet has been developed and successfully used in the rearing of larval gilthead seabream (Sparus aurata, Yúfera et al. 2000). One of the advantages on the use of microdiets is the possibility to manipulate its composition. This encapsulation method has been proved to successfully deliver bioactive compounds such as free amino acids, hormones, and vitamins to fish larvae (Yúfera et al. 2003).

The indispensable amino acid profile (or the $\mathrm{A} / \mathrm{E}$ ratios, i.e. $((\mathrm{IAA} /$ total IAA $) \times 1000)$ of fish carcass or muscle has been proposed as a good index of the indispensable amino acid requirements of larval (Watanabe and Kiron, 1994), juvenile, and adult fish (Wilson 1994; Mambrini and Kaushik 1995). However, a more precise estimate of the ideal dietary amino acid profile requires information on the relative bioavailabilities of the individual amino acids, in particular in what refers to possible differential rates of absorption and catabolism (Conceição et al. 2003b). This information together with the $\mathrm{A} / \mathrm{E}$ ratios of the larval protein should allow defining the ideal dietary amino profile for a given species (Conceição et al. 2003b).
Table 1. Ingredients used in the preparation of the experimental microcapsules $\left(\mathrm{g} \mathrm{kg}^{-1}\right.$ dry diet).

\begin{tabular}{|c|c|c|}
\hline Ingredients & IAAsup diet & DAAsup diet \\
\hline Casein ${ }^{1}$ & 400 & 400 \\
\hline Squid meal $^{2}$ & 62 & 61 \\
\hline Fish meal $^{3}$ & 72 & 63 \\
\hline Fish protein hydrolysate ${ }^{4}$ & 62 & 61 \\
\hline L-Histidine $^{5}$ & 19 & - \\
\hline L-Threonine $^{6}$ & 90 & - \\
\hline L-Arginine $^{7}$ & 28 & - \\
\hline L-Methionine $^{8}$ & 34 & - \\
\hline L-Cysteine ${ }^{9}$ & 16 & - \\
\hline L-Serine ${ }^{10}$ & - & 88 \\
\hline L-Alanine ${ }^{11}$ & - & 27 \\
\hline L-Glutamic acid ${ }^{12}$ & - & 52 \\
\hline L-Proline 13 & - & 34 \\
\hline Dextrin (type I) ${ }^{14}$ & 37 & 37 \\
\hline Fish oil ${ }^{15}$ & 93 & 91 \\
\hline Soy lecithin ${ }^{16}$ & 47 & 46 \\
\hline Vitamin $C^{17}$ & 30 & 30 \\
\hline Vitamin $\mathrm{E}^{18}$ & 10 & 10 \\
\hline
\end{tabular}

${ }^{1}$ ICN 901633; ${ }^{2}$ Rieber \& Sons, Norway; ${ }^{3}$ Aglonorse, Norway; ${ }^{4}$ CPSP 90, Sopropêche, France; ${ }^{5}$ Sigma H-8000; ${ }^{6}$ SigmaT-8625; 7 Aldrich A-92406; ${ }^{8}$ Sigma M-9625; 9 Aldrich 168149; ${ }^{10}$ Fluka 84960; ${ }^{11}$ Fluka 05129; ${ }^{12}$ Sigma G-1251; ${ }^{13}$ Sigma P-0380; ${ }^{14}$ ICN 101517; ${ }^{15}$ A1 DHA Selco; ${ }^{16}$ ICN 102147; ${ }^{17}$ Phospitan C, Showa Denko, Japan; ${ }^{18}$ DL-alpha-Tocopherol, ICN 100555.

The aim of this study was to analyse the effect of amino acid supplementation, in order to compensate for eventual dietary amino acid imbalances, on growth and survival of gilthead seabream larvae, using microencapsulated diets.

\section{Material and methods}

\subsection{Experimental diets}

Two experimental microencapsulated diets were formulated using the A/E ratios (Arai 1981) of larval seabream obtained by Aragão et al. (2004a) as a guideline. These values were corrected with the relative bioavailabilities of each amino acid, according to the results obtained by Conceição et al. (2003b). The basal formulation was identical for both microcapsules, but different crystalline L-amino acids (from Sigma-Aldrich, Germany) were included in order to obtain two different dietary amino acid profiles. One of the microdiets (IAAsup) was supplemented with indispensable amino acids in order to obtain dietary $\mathrm{A} / \mathrm{E}$ ratios similar to the $\mathrm{A} / \mathrm{E}$ ratios of larval seabream [accordingly to the results of Aragão et al. (2004a) and taking into account the relative bioavailabilities of each amino acid (Conceição et al. 2003b)]. The other microdiet (DAAsup) was supplemented with dispensable amino acids.

The microencapsulated diets were prepared by interfacial polymerisation of the dietary protein. The dietary ingredients are shown in Table 1. The process is described in detail by Yúfera et al. (2000). The microcapsules were freeze-dried 
and then sieved into the range between 200 and $400 \mu \mathrm{m}$. Dietary samples were analysed for free and protein-bound amino acids.

Leaching tests from microencapsulated diets were carried out according to Yúfera et al. (2002). At time zero, $56 \mathrm{mg}$ of microcapsules were added to $25 \mathrm{ml}$ of distilled water. Water samples of $5 \mathrm{ml}$ were taken at 5 and $60 \mathrm{~min}$, using a $10 \mathrm{ml}$ syringe. These samples were filtered through a $0.45 \mu \mathrm{m}$ membrane and further analysed for free amino acid content.

\subsection{Fish rearing and sampling}

Eggs were obtained from natural spawning of seabream broodstock maintained at the IPIMAR research station (Olhão, Portugal) and larval rearing was carried out at the CCMAR experimental station (Faro, Portugal). Seabream were reared in a recirculating system comprising $100 \mathrm{~L}$ conical-cylindrical fibreglass white tanks, according to standard rearing procedures (Moretti et al. 1999). During this initial rearing period larvae were fed exclusively on live prey (rotifers and Artemia) enriched with commercial products.

At 28 days after hatching (DAH) larvae were counted and distributed into nine tanks, identical to the ones used for larval rearing, at a density of 6.5 larvae $\mathrm{L}^{-1}$. A group of 20 larvae from the initial stock was measured, weighed, and frozen for posterior analysis of dry weight and amino acid content. The experiment started at 33 DAH and lasted 10 days. During the experiment water flow rate was $16.7 \mathrm{~L} \mathrm{~h}^{-1}$ and temperature $\left(19.3 \pm 0.2{ }^{\circ} \mathrm{C}\right)$, salinity $(36 \pm 1 \mathrm{ppt})$, and dissolved oxygen (97 $\pm 2 \%$ saturation) were measured daily. A $24 \mathrm{~h}$ light cycle was adopted, although from $05 \mathrm{~h} 00$ to $09 \mathrm{~h} 00$ the light intensity was reduced.

Each experimental microdiet was randomly assigned to triplicate tanks. The microcapsules were distributed by automatic feeding devices from $10 \mathrm{~h} 00$ to $04 \mathrm{~h} 00$, in six meals per day $(2 \mathrm{~h}$ each), with $1 \mathrm{~h}$ interval between each meal. In other three tanks (reference treatment) larvae were fed with Artemia metanauplii enriched for 24-h with Ratio HUFA (Salt Creek Inc., Utah, USA), three times a day, during the whole experimental period. Microcapsules and Artemia were provided in excess.

Survival was daily monitored. At the end of the experiment, the remaining fish in each tank was counted and 20 larvae from each tank were measured and frozen for subsequent determinations of individual dry weight after freeze-drying.

\subsection{Amino acid analysis}

Dietary samples were analysed for free and protein-bound amino acid content. Extraction of free amino acids and sample deproteinisation were carried out according to Cohen et al. (1989). Both larval and dietary samples were hydrolysed (6 $\mathrm{M} \mathrm{HCl}$ at $106{ }^{\circ} \mathrm{C}$ over $24 \mathrm{~h}$ in nitrogen-flushed glass vials), after free amino acid extraction, for protein-bound amino acid analysis. Both free and protein-bound amino acids were analysed by High Pressure Liquid Chromatography (HPLC) in a Pico-Tag Amino Acid Analysis System (Waters, USA), using norleucine as internal standard and according to the procedures described by Cohen et al. (1989). The protein-bound tryptophan was not determined, since it is partially destroyed by acid hydrolysis. Asparagine is converted to aspartate and glutamine to glutamate during acid hydrolysis, so the reported values for these amino acids (Asx and Glx) represent the sum of the respective amine and amino acid in the proteins. Resulting peaks were analysed using the Breeze software (Waters).

\subsection{Data analysis}

The A/E ratios (Arai 1981) were calculated as: (each indispensable amino acid content) $\times$ (total indispensable amino acid content including cysteine and tyrosine $)^{-1} \times 1000$. A dietary imbalance for a given indispensable amino acid is assumed to occur when its $\mathrm{A} / \mathrm{E}$ ratio in the fish is higher than the $\mathrm{A} / \mathrm{E}$ ratio in the food item.

Relative growth rate (RGR, \% dry weight day ${ }^{-1}$ ) was calculated as: $\mathrm{RGR}=\left(\mathrm{e}^{g}-1\right) \times 100$, where $g=\left(\ln W_{t}-\ln W_{0}\right) \times t^{-1}$, $W_{t}$ and $W_{0}$ are the final and initial dry weights, respectively, and $t$ is the duration of the trial. Total biomass production has been estimated from the total increase in population dry weight per weight unit during the experimental time.

The results are expressed as means \pm standard deviation (SD). Data were tested by one-way ANOVA followed by Bonferroni $t$-test. The significance level used was $p \leqslant 0.05$.

\section{Results}

The amino acid composition of the experimental microcapsules is given in Table 2. The IAAsup diet presented more $24 \%$ of histidine, $73 \%$ of threonine, $7 \%$ of arginine, $9 \%$ of methionine, and $2100 \%$ of cysteine than the DAAsup diet. On the contrary, the DAAsup diet had more $3 \%$ of glutamic acid, $8 \%$ of serine, and $7 \%$ of proline than the IAAsup diet. The IAAsup diet had significantly more amino acids in the free form than the DAAsup diet $\left(13.3 \pm 2.0 \mathrm{mg} \mathrm{g}^{-1} \mathrm{DW}\right.$ versus $6.9 \pm 0.1 \mathrm{mg} \mathrm{g}^{-1} \mathrm{DW}$, respectively), corresponding to 3 and $1.5 \%$ of the total amino acids, respectively. The IAA:DAA ratio was significantly higher in IAAsup than in DAAsup diet $(1.05 \pm 0.02$ versus $0.93 \pm 0.02$, respectively; $p<0.01)$.

Leaching from both microcapsules seemed to occur especially during the first 5 min of immersion in water (Table 3), with some exceptions. Regarding the loss of each specific free amino acid (FAA) supplemented to the diets [(micrograms of each FAA found in water $) \times($ micrograms of each FAA in microdiet before immersion $)^{-1} \times 100$ ], in the IAAsup diet $60 \%$ of free histidine and $40 \%$ of free cysteine had leached into the water within $5 \mathrm{~min}$ of immersion, but these values remained stable until $1 \mathrm{~h}$ after immersion. However, $10 \%$ of free arginine and $40 \%$ of free methionine had leached into the water $5 \mathrm{~min}$ after immersion, but these values increased, respectively, to 33 and $95 \%$ after $1 \mathrm{~h}$ of immersion. The leaching of free threonine was very low, attaining $10 \%$ after $1 \mathrm{~h}$ of immersion. In the DAAsup diet, $40 \%$ of the free serine and $50 \%$ of free alanine had leached into the water after $5 \mathrm{~min}$ of immersion and these values increased up to more or less $90 \%$ after $1 \mathrm{~h}$. All the free proline and glutamic acid in the DAAsup diet had leached 
Table 2. Amino acid (AA) composition of experimental microcapsules (sum of free and protein-bound AA) and percentage present in the free form [calculated for each AA as: free AA $\left.\times(\text { free } \mathrm{AA}+\text { protein-bound } \mathrm{AA})^{-1} \times 100\right]$.

\begin{tabular}{ccccc}
\hline & \multicolumn{2}{c}{ IAAsup diet } & \multicolumn{2}{c}{ DAAsup diet } \\
\hline AA & $\begin{array}{c}\text { Total AA } \\
\left(\mathrm{mgA}^{-1} \mathrm{DW}\right)\end{array}$ & AA in free form & $\begin{array}{c}\text { Total AA } \\
\left(\mathrm{mg} \mathrm{AA} \mathrm{g}^{-1} \mathrm{DW}\right)\end{array}$ & AA in free form \\
\hline His & $\mathbf{1 1} \pm \mathbf{3}$ & $\mathbf{3 \%}$ & $9 \pm 3$ & ND \\
Thr & $\mathbf{2 7} \pm \mathbf{6}$ & $\mathbf{3 4 \%}$ & $16 \pm 4$ & ND \\
Arg & $\mathbf{2 4} \pm \mathbf{8}$ & $\mathbf{4 \%}$ & $22 \pm 6$ & ND \\
Val & $30 \pm 8$ & ND & $30 \pm 7$ & ND \\
Met & $\mathbf{1 3} \pm \mathbf{4}$ & $\mathbf{1 3 \%}$ & $12 \pm 2$ & ND \\
Ile & $23 \pm 6$ & ND & $22 \pm 4$ & ND \\
Leu & $39 \pm 10$ & ND & $38 \pm 8$ & ND \\
Phe & $18 \pm 5$ & ND & $18 \pm 3$ & ND \\
Lys & $31 \pm 8$ & ND & $29 \pm 8$ & $2.6 \%$ \\
Tyr & $18 \pm 5$ & $2 \%$ & $18 \pm 4$ & $100 \%$ \\
Cys & $\mathbf{4} \pm \mathbf{1}$ & $\mathbf{1 5 \%}$ & $24 \pm 8$ & ND \\
Asx & $26 \pm 5$ & $0.6 \%$ & $\mathbf{7 2} \pm \mathbf{1 9}$ & $\mathbf{2 \%}$ \\
Glx & $70 \pm 18$ & ND & $\mathbf{3 5} \pm \mathbf{8}$ & $\mathbf{5 \%}$ \\
Ser & $32 \pm 8$ & ND & $26 \pm 7$ & ND \\
Gly & $26 \pm 7$ & ND & $\mathbf{2 3} \pm \mathbf{5}$ & $\mathbf{6 \%}$ \\
Ala & $24 \pm 6$ & ND & $\mathbf{5 2} \pm \mathbf{1 2}$ & $\mathbf{3 \%}$ \\
Pro & $49 \pm 12$ & ND & & \\
\hline
\end{tabular}

Results are expressed as means $\pm \mathrm{SD}(n=3)$. DW = dry weight; ND = not detectable or vestigial. AA that were supplemented to the microcapsules are given in bold.

Table 3. Leaching of each free amino acid (FAA) from the experimental microcapsules after 5 and 60 min of immersion in water.

\begin{tabular}{ccccc}
\hline & \multicolumn{2}{c}{ IAAsup diet } & \multicolumn{2}{c}{ DAAsup diet } \\
\hline AA & 5 min & $60 \mathrm{~min}$ & $5 \mathrm{~min}$ & $60 \mathrm{~min}$ \\
\hline His & $\mathbf{6 1}$ & $\mathbf{6 2}$ & - & - \\
Thr & $\mathbf{6}$ & $\mathbf{1 0}$ & - & - \\
Arg & $\mathbf{1 0}$ & $\mathbf{3 3}$ & - & - \\
Tyr & 100 & 100 & 100 & 100 \\
Met & $\mathbf{4 3}$ & $\mathbf{9 5}$ & - & - \\
Cys & $\mathbf{4 0}$ & $\mathbf{4 0}$ & 100 & 100 \\
Asx & 50 & 59 & 100 & 100 \\
Glx & 100 & 100 & $\mathbf{1 0 0}$ & $\mathbf{1 0 0}$ \\
Ser & - & - & $\mathbf{4 0}$ & $\mathbf{9 3}$ \\
Gly & 100 & 100 & 52 & 52 \\
Ala & - & - & $\mathbf{5 0}$ & $\mathbf{8 9}$ \\
Pro & - & - & $\mathbf{1 0 0}$ & $\mathbf{1 0 0}$ \\
\hline
\end{tabular}

Note: the loss of each specific FAA was calculated as a percentage of that FAA in the microencapsulated diet: (micrograms of each FAA found in water) $\times$ (micrograms of each FAA in microdiet before immersion $)^{-1} \times 100$. AA that were supplemented to the microcapsules are given in bold.

into the water within 5 min of immersion. However, when expressed as the total loss of free amino acids from the microcapsules [(micrograms of total FAA in water $) \times($ micrograms of total FAA in microdiet before immersion $\left.)^{-1} \times 100\right]$, the leaching losses represent only 20 and $31 \%$ of the total initial free amino acid content in the IAAsup diet, after 5 and 60 min of
Table 4. Survival and growth of Sparus aurata larvae fed microcapsules supplemented with amino acids (IAAsup and DAAsup) or Artemia metanauplii. RGR: relative growth rate.

\begin{tabular}{ccccc}
\hline Treatments & $\begin{array}{c}\text { Survival } \\
(\boldsymbol{\%})\end{array}$ & $\begin{array}{c}\text { Total length } \\
(\mathbf{m m})\end{array}$ & $\begin{array}{c}\text { Dry weight } \\
(\mathbf{m g})\end{array}$ & $\begin{array}{c}\text { RGR } \\
\left(\boldsymbol{\%} \mathbf{d a y}^{-1}\right)\end{array}$ \\
\hline IAAsup & $75 \pm 6^{\mathrm{a}}$ & $12.0 \pm 1.2^{\mathrm{b}}$ & $2.3 \pm 0.7^{\mathrm{b}}$ & $9.0 \pm 1.6^{\mathrm{ab}}$ \\
DAAsup & $52 \pm 9^{\mathrm{b}}$ & $11.8 \pm 1.1^{\mathrm{b}}$ & $2.0 \pm 0.7^{\mathrm{b}}$ & $7.5 \pm 0.5^{\mathrm{b}}$ \\
Artemia & $87 \pm 5^{\mathrm{a}}$ & $13.0 \pm 1.6^{\mathrm{a}}$ & $3.2 \pm 1.3^{\mathrm{a}}$ & $12.9 \pm 2.8^{\mathrm{a}}$ \\
\hline
\end{tabular}

Values are means $\pm \mathrm{SD}(n=3)$ and different superscripts within the same column indicate significant differences between treatments $(p<0.02)$. Initial total length and dry weight were, respectively, $9.9 \pm 1.2 \mathrm{~mm}$ and $1.1 \pm 0.1 \mathrm{mg}$ for all treatments.

immersion in water, respectively. On the contrary, the total loss of free amino acids in the DAAsup diet was very high: after 5 min of immersion in water the leaching losses accounted for $75 \%$ of the total initial free amino acid content, and this value increased to $94 \%$ after $1 \mathrm{~h}$ of immersion. It should be noted that the larval seabream readily accepted both microcapsules and the majority of the larvae were picking up the feed from the water surface within 5 min after deliver.

Figure 1 shows that the IAAsup diet seems to have A/E ratios more similar to the ones of larval seabream than the DAAsup diet. The IAAsup diet still seems to be deficient in arginine and lysine, while these same amino acids plus threonine and sulphur amino acids seem to be deficient in the DAAsup diet. The comparison of the A/E ratios of larval seabream with the $\mathrm{A} / \mathrm{E}$ ratios of Artemia metanauplii (results not shown), suggest 


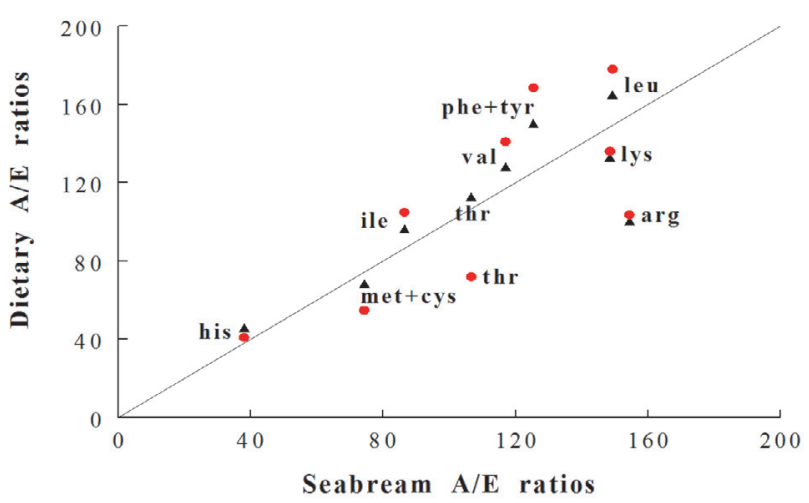

Fig. 1. Comparison of the A/E ratios of Sparus aurata larvae (corrected for the different amino acid bioavailabilities) with the dietary $\mathrm{A} / \mathrm{E}$ ratios (corrected for the leaching losses of free amino acids after 5 min of immersion in water). $\mathbf{\Delta}$ : Microcapsules IAAsup (supplemented with Indispensable amino acids); $\bullet$ : microcapsules DAAsup (supplemented with Dispensable amino acids). The comparison with the A/E ratios of Artemia metanauplii is not shown, since most of the points overlap with the DAAsup diet.

that Artemia is deficient in threonine, sulphur amino acids, and arginine for the seabream larvae. These dietary deficiencies are in the same order of magnitude as the ones found for the DAAsup diet, with the exception of arginine that seems to be less deficient in Artemia than in both microcapsules.

After four days of experiment, larval groups eating both microcapsules started to display moderate mortality. The pattern of mortality was similar in both treatments, but larvae fed the DAAsup diet had a higher mortality during the experimental period. This resulted in a significantly higher mortality at the end of the experiment in larvae fed the DAAsup than the IAAsup diet or Artemia (Table 4). In 10 days of experiment, larvae from all treatments more than doubled their average dry weight (Table 4). At the end of the experiment, length and weight between groups fed with microcapsules was similar, but significantly lower than in larvae fed with Artemia. When growth is expressed as RGR (Table 4) or total biomass production (Fig. 2), it is seen that both parameters tended to be higher, although not statistically significant, in larvae fed the IAAsup than the DAAsup diet. Only in this last treatment growth was significantly lower in comparison with larvae fed with Artemia.

\section{Discussion}

The casein-based microencapsulated diet used in the current study has been used successfully in previous studies with larval gilthead seabream (Yúfera et al. 1999, 2000, 2003). However, this is the first time that it is used in latter stages of development. In previous studies, growth in seabream feeding microcapsules from 6 to $22 \mathrm{DAH}$ was similar to that observed using live food, but only at $22{ }^{\circ} \mathrm{C}$; at $18{ }^{\circ} \mathrm{C}$ the growth was significantly lower (Yúfera et al. 2000). Since the current

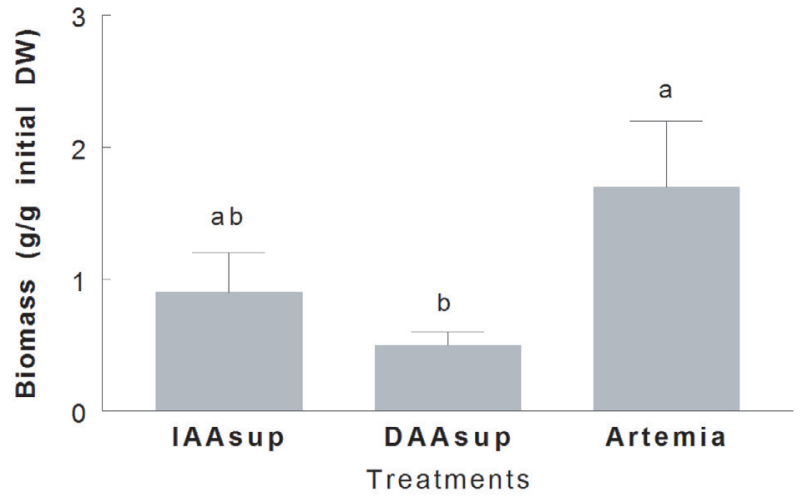

Fig. 2. Total biomass production (g per g initial dry weigh) of Sparus aurata larvae fed microcapsules supplemented with amino acids (IAAsup and DAAsup) or Artemia metanauplii. Means \pm SD $(n=3)$. Different letters indicate significant differences among treatments $(p=0.01)$.

experiment was conducted at $19^{\circ} \mathrm{C}$, this may be one of the reasons for the lower growth in larvae eating both microcapsules than in larvae eating Artemia. Moreover, it has been proposed that several metabolites released by Artemia stimulate ingestion rates in fish larvae (Kolkovski et al. 1997b). Therefore, it is likely that after the change from Artemia to microcapsules the larvae had a lower food intake, which probably affected the larval growth rate during the first days of experiment.

When working with living larvae of marine fish, the assessment of an experimental microdiet with modified formulation in terms of potential growth enhancement has many constrains. Growth response depends of several variables not only related to microparticle characteristic (i.e. formulation or leaching rate of soluble compounds) but also with the larvae, such as feeding behaviour, digestive and absorptive capacities (Yúfera et al. 2003). All these aspects are especially relevant in the case of dietary proteins, peptides, and amino acids (Kvåle et al. 2007). In addition, the final response can be restricted by the deficiency in other nutrient. Taken into account these restrictions and experimental difficulties, two assumptions were considered in the present study to have a realistic scenario for the diet comparison: a) the amino acid leaching in seawater is similar or lower than that determined in freshwater, b) the microdiet composition after $5 \mathrm{~min}$ of immersion in water is representative of the ingested composition.

In this study the effect of amino acid supplementation on individual larval growth was not as notable as expected. Nevertheless, the average dry weight doubled during the experimental period and therefore dietary deficiencies are probably reflected. This is further supported by the significant differences in mortality between treatments. A balanced dietary amino acid profile has been shown to increase the amino acid retention in Senegalese sole postlarvae (Aragão et al. 2004c) and since growth is essentially protein deposition (Carter and Houlihan 2001), an improvement in growth performance was expected in seabream larvae fed the IAAsup diet. Dietary 
amino acid imbalances were significantly reduced in the IAAsup compared with the DAAsup diet, although arginine may still be limiting growth. Moreover, amino acid imbalances affect more seriously the fish when the dietary protein content is low, since in this case protein synthesis is seriously compromised.

The amino acid supplementation resulted in different IAA:DAA ratios and studies with rainbow trout revealed that feed intake and feed efficiency ratio increase with increasing dietary IAA:DAA ratios (up to 1.33; Green et al. 2002). As a result, higher nitrogen retention and growth rates and lower nitrogen excretion were observed in that study. However, in the present study, besides the reduction in dietary amino acid deficiencies and the increased IAA:DAA ratio in IAAsup diet, only a tendency for a higher growth rate and total biomass production in larvae fed this than the DAAsup diet was observed. This may be linked with the possible decrease in growth rates during the first days of experiment, as already mentioned. Further studies using long-term experiments or introducing the microcapsules earlier in order to avoid a long period of feeding with Artemia seem necessary.

The indispensable amino acid supplementation was not sufficient efficient to increase larval growth rates in short term, however it resulted in an increased survival of seabream larvae eating these microcapsules. Dietary deficiencies in amino acids may have major implications for larval development, other than effects on growth. For instance, a dietary tryptophan deficiency has been reported to induce scoliosis in salmonids (Cahu et al. 2003), while dietary amino acid profile has been shown to affect swim bladder inflation in striped bass larvae (Hughes 2003). On the other hand, scale deformities and vertebral abnormalities were found in rainbow trout fed with a high leucine diet (Choo et al. 1991). Regarding survival, some studies in fish juveniles show an increase in survival when the dietary arginine or sulphur amino acid requirements are met (Alam et al. 2002; Goff and Gatlin III 2004).

Therefore, dietary supplementation with indispensable amino acids in order to obtain a more balanced amino acid profile significantly increased survival. Further studies introducing microcapsules earlier in the development seem necessary in order to optimise growth performances.

Acknowledgements. The authors acknowledge funding by project AGL2004-06669-C02-01 (MCYT, Spain) and grant SFRH/BPD/14835/2003 (FCT, Portugal). Technical support given by Helena Damásio during larval rearing is greatly appreciated.

\section{References}

Alam M.S., Teshima S., Koshio S., Ishikawa M., 2002, Arginine requirement of juvenile Japanese flounder Paralichthys olivaceus estimated by growth and biochemical parameters. Aquaculture 205, 127-140.

Aragão C, Conceição L.E.C., Fyhn H.J., Dinis M.T., 2004a, Estimated amino acid requirements during early ontogeny in fish with different life styles: gilthead seabream (Sparus aurata) and Senegalese sole (Solea senegalensis). Aquaculture 242, 589-605.
Aragão C., Conceição L.E.C., Dinis M.T., Fyhn H.J., 2004b, Amino acid pools of rotifers and Artemia under different conditions: nutritional implications for fish larvae. Aquaculture 234, 429-445.

Aragão C., Conceição L.E.C., Martins D., Rønnestad I., Gomes E., Dinis M.T., 2004c, A balanced dietary amino acid profile improves amino acid retention in post-larval Senegalese sole (Solea senegalensis). Aquaculture 233, 293-304.

Arai S., 1981, A purified test diet for coho salmon, Oncorhynchus kisutch, fry. Bull. Jpn. Soc. Sci. Fish. 47, 547-550.

Ballantyne J.S., 2001, Amino acid metabolism. In: Wright PA, Anderson AJ (Eds.) Nitrogen Excretion. Fish Physiology 20, Academic Press, San Diego, USA, pp. 77-107.

Cahu C.L., Zambonino Infante J.L., Takeuchi T., 2003, Nutritional components affecting skeletal development in fish larvae. Aquaculture 227, 245-258.

Carter C.G., Houlihan D.F., 2001, Protein synthesis. In: Wright PA, Anderson AJ (Eds.) Nitrogen Excretion. Fish Physiology, Vol.20, Academic Press, San Diego, USA, pp. 31-75.

Choo P.-S., Smith T.K., Cho C.Y., Ferguson H.W., 1991, Dietary excesses of leucine influence growth and body composition of rainbow trout. J. Nutr. 121, 1932-1939.

Cohen S.A., Meys M., Tarvin T.L., 1989, The Pico-Tag Method A Manual of Advanced Techniques for Amino Acid Analysis. Waters, Bedford, USA.

Conceição L.E.C., Grasdalen H., Rønnestad I., 2003a, Amino acid requirements of fish larvae and post-larvae: new tools and recent findings. Aquaculture 227, 221-232.

Conceição L.E.C., Grasdalen H., Dinis M.T., 2003b, A new method to estimate the relative bioavailability of individual amino acids in fish larvae using ${ }^{13} \mathrm{C}$-NMR spectroscopy. Comp. Biochem. Physiol. B 134, 103-109.

Fernández-Díaz C., Yúfera M., 1997, Detecting growth in gilthead seabream, Sparus aurata L, larvae fed microcapsules. Aquaculture 153, 93-102.

Goff J.B., Gatlin III D.M., 2004, Evaluation of different sulfur amino acid compounds in the diet of red drum, Sciaenops ocellatus, and sparing value of cystine for methionine. Aquaculture 241, 465477.

Green J.A., Hardy R.W., Brannon E.L., 2002, The optimum dietary essential: nonessential amino acid ratio for rainbow trout (Oncorhynchus mykiss), which maximizes nitrogen retention and minimizes nitrogen excretion. Fish Physiol. Biochem. 27, 109115.

Hughes S.G., 2003, Tests of a microencapsulated amino acid diet for larval and juvenile striped bass. World Aquac. 34, 12-15.

Kvåle A., Nordgreen A., Tonheim S.K., Hamre K., 2007, The problem of meeting dietary protein requirements in intensive aquaculture of marine fish, with emphasis on Atlantic halibut (Hippoglossuss hippoglossus L.). Aquac. Nutr. 13, 170-185.

Kolkovski S., Tandler A., Izquierdo M.S., 1997a, Effects of live food and dietary digestive enzymes on the efficiency of microdiets for seabass (Dicentarchus labrax) larvae. Aquaculture 148, 313-322.

Kolkovski S., Arieli A., Tandler A., 1997b, Visual and chemical cues stimulate microdiet ingestion in sea bream larvae. Aquac. Int. 5, 527-536.

Mambrini M., Kaushik S.J., 1995, Indispensable amino acid requirements of fish: correspondence between quantitative data and amino acid profiles of tissue proteins. J. Appl. Ichthyol. 11, 240247.

Moretti A., Fernadez-Criado M.P., Cittolin G, Guidastri R, 1999, Manual on Hatchery Production of Seabass and Gilthead Seabream. Food and Agriculture Organization of the United Nations, Rome, Italy. 
Rønnestad I., Conceição L.E.C., 2005, Aspects of protein and amino acids digestion and utilization by marine fish larvae. In: Starck JM, Wang T (Eds.) Physiological and Ecological Adaptations to Feeding in Vertebrates, Science Publishers, Enfield, New Hampshire, USA, pp. 389-416.

Takeuchi T., Wang Q., Furuita H., Hirota T., Ishida S., Hayasawa H., 2003, Development of microparticle diets for Japanese flounder Paralichthys olivaceus larvae. Fish. Sci. 69, 547-554.

Tandler A., Kolkovski S., 1991, Rates of ingestion and digestibility as limiting factors in the successful use of microdiets in Sparus aurata larval rearing. In: Lavens $\mathrm{P}$, Sorgeloos $\mathrm{P}$, Jaspers E, Ollevier F (Eds.) Larvi'91 - Fish \& Crustacean Larviculture Symposium, European Aquaculture Society, Special Publication No. 15, Gent, Belgium, pp. 169-171.

Yúfera M., Pascual E., Fernández-Díaz C., 1999, A highly efficient microencapsulated food for rearing early larvae of marine fish. Aquaculture 177, 249-256.
Yúfera M., Fernández-Díaz C., Pascual E., Sarasquete M.C., Moyano F.J., Díaz M., Alarcón F.J., García-Gallego M., Parra G., 2000, Towards an inert diet for first-feeding gilthead seabream Sparus aurata L. larvae. Aquacult. Nutr. 6, 143-152.

Yúfera M., Kolkovski S., Fernández-Díaz C., Dabrowski K., 2002, Free amino acid leaching from a protein-walled microencapsulated diet for fish larvae. Aquaculture 214, 273-287.

Yúfera M., Kolkovski S., Fernández-Díaz C., Rinchard J., Lee K.J., Dabrowski K., 2003, Delivering bioactive compounds to fish larvae using microencapsulated diets. Aquaculture 227, 277-291.

Watanabe T., Kiron V., 1994, Prospects in larval fish dietetics. Aquaculture 124, 223-251.

Wilson R.P., 1994, Amino Acid Requirements of Finfish. In: D'Mello JPF (Ed.) Amino Acids in Farm Animal Nutrition, CAB International, Wallingford, UK, pp. 377-399. 